\title{
Democracia, gênero e laicidade: contribuições da teologia feminista
}

\author{
(Democracy, gender and secularism: contributions of feminist theology)
}

(Democracia, género y laicismo: contribuciones de la teología feminista)

n. $16, v .1$

André Luís da Rosa ${ }^{1}$ Javier Ignacio Vernal $^{2}$

RESUMO: Diante do avanço do conservadorismo religioso cristão na esfera política brasileira, tornou-se necessário um olhar dos movimentos e teorias feministas sobre tal fenômeno, pois são considerados uma ameaça para a sociedade, à moral e à família pelos religiosos. Nesse sentido, tem-se como objetivo apresentar algumas contribuições da Teologia Feminista, que tem sido pioneira nos estudos sobre gênero e religião, para a reflexão e a luta contra o fundamentalismo religioso e pela laicidade do Estado. Para tanto, no primeiro momento, será analisada brevemente a compreensão de gênero e sexualidade do catolicismo, que é baseada principalmente na denominada 'lei natural'. No segundo momento, apresentar-se-á o surgimento da Teologia Feminista no Brasil, que teve seu terreno preparado pela Teologia da Libertação. E, por fim, se refletirá sobre as relações entre democracia, gênero e laicidade a partir da Teologia Feminista.

PALAVRAS-CHAVE: Teologia Feminista. Gênero. Democracia. Laicidade.

\begin{abstract}
In view of the advancement of Christian religious conservatism in the Brazilian political sphere, it became necessary to look at feminist movements and theories about this phenomenon, since they are considered a threat to society, morals and the family by religious people. In this sense, this article aims to present some contributions from Feminist Theology, which has been a pioneer in studies on gender and religion, for reflection and for the fight against religious fundamentalism and for the secularity of the State. Therefore, in the first moment, the understanding of gender and sexuality of Catholicism will be briefly analyzed, which is based mainly on the so-called natural law. In the second moment, the emergence of Feminist Theology in Brazil will be presented, which had its terrain prepared by Liberation Theology. Finally, this article will reflect on the relations among democracy, gender and secularism based on Feminist Theology.

Keywords: Feminist Theology. Gender. Democracy. Secularity.
\end{abstract}

Resumen: Visto que ha avanzado el conservadurismo religioso cristiano en la esfera política brasileña, se hizo necesario una mirada hacia los movimientos y teorías feministas sobre este fenómeno, ya que los religiosos los consideran una amenaza para la sociedad, la moral y la familia. Este artículo tiene como objetivo presentar algunas contribuciones de la teología feminista, que ha sido pionera en estudios sobre género y religión en la reflexión y la lucha contra el fundamentalismo religioso y para la secularidad del Estado. En un primer momento, se analizará brevemente la comprensión del género y la sexualidad del catolicismo, que se basa principalmente en la llamada ley natural. En el segundo momento, se presentará el surgimiento de la teología feminista en Brasil, que tuvo su terreno preparado por la teología de la liberación. Y, finalmente, se reflexionará sobre las relaciones entre democracia, género y secularidad basadas en la teología feminista.

Palabras clave: Teología Feminista. Género. Democracia. Secularidad.

1 Doutorando em Ciências Humanas pela Universidade Federal de Santa Catarina (UFSC). E-mail: andreldarosa@hotmail.com.

2 Doutor em Filosofia pela Universidade Federal de Santa Catarina (UFSC). Professor no Programa de Pós-Graduação Interdisciplinar em Ciências Humanas da UFSC. E-mail: jivernal@gmail.com. 
O discurso teológico cristão conservador tenta se impor com ainda mais veemência sempre que seus representantes e defensores avaliam que seus interesses e visão de mundo são ameaçados ou, pelo menos, questionados. Assim ocorreu, por exemplo, nos anos 1970 nos Estados Unidos da América, e desse modo vem também ocorrendo no Brasil desde o golpe de 2016 contra a presidenta Dilma Rousseff, e com mais força a partir da eleição presidencial de 2018, na qual o candidato vencedor, Jair Messias Bolsonaro (então do PSL e hoje sem partido), associou por inúmeras vezes sua campanha eleitoral à narrativa religiosa fundamentalista cristã, tendo como slogan político/religioso "Brasil acima de tudo, Deus acima de todos". (TESSER, 2019) Os religiosos fundamentalistas cristãos construíram em torno de Bolsonaro uma imagem messiânica, criando nele uma imagem pública/política com características que o comparam a Jesus Cristo, martirizado e morto pelo Império Romano.

O episódio do atentado à faca, por exemplo, reforçou a ideia de sacrifício e sofrimento, ligando-o ao Jesus torturado, injustiçado, demonstrando a via dolorosa que Bolsonaro enfrentou para salvar a Nação. (PY, 2019) Após o atentado, o então candidato afirmou em entrevista: “os médicos dizem que eu estou vivo por uma obra de Deus, um milagre aconteceu”. (BOLSONARO, 2018) Isso confirmava para os religiosos que Bolsonaro era o "ungido da Nação”, o candidato “eleito por Deus” para derrotar os seus inimigos: os partidos de esquerda, a “ideologia de gênero" nas escolas, as Universidades que promovem a doutrinação comunista, as pautas dos movimentos feministas e LGBTQIA+, dentre outros.

Os setores religiosos fundamentalistas (católicos de grupos carismáticos e tradicionalistas e (neo)pentecostais) têm conquistado uma expressiva força política no Brasil devido a uma reposição de temas na agenda política da maioria dos grupos religiosos que favorecem e defendem questões de cunho moral e privado (SILVA, 2018), certamente como reação frente às conquistas progressistas obtidas em anos anteriores. Estes setores religiosos creem-se como arautos de um dever moral de participar da política e de mudá-la, sobretudo no que se refere ao avanço de pautas identificadas com os Direitos Humanos ou com as minorias, entendidas por tais segmentos como 'trevas' a serem combatidas pela participação política, encarada nos termos de uma 'batalha espiritual'.

Diante deste atual quadro da participação política religiosa, torna-se uma página necessária aos estudos feministas a compreensão do fenômeno religioso. Nesse sentido, o presente artigo tem como objetivo apresentar algumas contribuições da Teologia Feminista (TF), que tem sido pioneira nos estudos sobre gênero e religião, para a reflexão e a luta contra o fundamentalismo religioso e pela laicidade do Estado. 


\section{Condenadas pela natureza: gênero e sexualidade no catolicismo}

As fileiras de fiéis do catolicismo são compostas em sua maioria por mulheres, mas elas não podem exercer nenhum espaço de poder e decisão nesta instituição. A Igreja se erige nas suas vidas como uma extensão do espaço doméstico: são secretárias dos padres, catequistas, faxineiras. Com a instituição do celibato obrigatório para os padres, a Igreja realizou a total exclusão das mulheres, pois elas não possuem mais nem o direito de serem esposas dos padres. (RANKE-HEINEMANN, 2019) Em torno desta misoginia institucional, desenvolveu-se toda uma teologia para justificá-la, o que possui até hoje implicações políticas em nossa sociedade, ao pregarem a imagem bíblica da mulher silenciosa, sofredora e obediente, baseando-se na devoção mariana. Assim, segundo Castro (2013, p. 148), são valorizadas a submissão e a docilidade, pois esses valores estão associados à essência da mulher em oposição aos atributos masculinos, ou seja, “o marianismo normatizaria papéis para homens e mulheres cristãos e seria uma forma de demarcar os espaços reservados às mulheres, ou seja, as posições que podem ocupar na sociedade”.

A moral cristã tradicional ${ }^{3}$, baseia-se na denominada lei natural, pois, segundo o padre Anderson Marçal (2009), da comunidade carismática Canção Nova: “nenhuma lei feita pelos homens pode perturbar a norma escrita pelo Criador, sem que a sociedade venha ser dramaticamente ferida nisto que constitui o seu fundamento basilar. Esquecê-lo significaria demolir a família, penalizar os filhos e render incerto o futuro da sociedade”. Visão essa fundamentada no Catecismo da Igreja Católica (1993), número 1979, que reza: “a lei natural é imutável, permanece através da história. As regras que a exprimem são substancialmente sempre válidas. Ela é uma base necessária para a edificação das regras morais e para a lei civil”. A lei natural, para a Igreja Católica, não deve fundamentar apenas os seus dogmas, mas deve ser a lei sob a qual devem ser pensadas as leis de todas as sociedades.

Em relação ao movimento feminista, o principal embate da Igreja Católica, fundamentada na lei natural, diz respeito aos direitos reprodutivos das mulheres, como explica o Padre Jonas Eduardo (2009), da comunidade carismática Canção Nova:

O direito não pode prescindir dos ditames da lei natural (exigências éticas intrínsecas à natureza humana). Matar um inocente é antinatural (nossa vida não nos pertence, é-nos dada e tirada por Alguém maior) e, portanto, pecado grave (se cometido de modo livre e consciente) e justamente condenável no âmbito cívil (crime) e eclesiástico (excomunhão).

\footnotetext{
3 Neste artigo priorizamos a teologia católica, mas, deve-se ressaltar que mesmo tratando-se de grupos religiosos distintos, em relação às questões de gênero e sexualidade, católicos e (neo)pentecostais coincidem em vários posicionamentos. Eles atuaram e atuam em aliança na Bancada Evangélica em diversos projetos, como: Estatuto da Família e do Nascituro e Projeto Escola Sem Partido.
} 
Para ele, é um dado científico que a partir do momento da fecundação um novo ser humano se faz presente em nosso mundo e em nossa história, e essa nova vida já possui alma e foi criada por Deus, por isso, o aborto não se justifica em nenhuma situação. O Padre Jonas Eduardo (2009) defende até, por exemplo, a continuidade da gestação mesmo em uma menina de 9 anos que foi estuprada, como afirma: “é uma falácia afirmar que a gravidez aos 9 anos põe necessariamente a menina em risco de vida - os dados da literatura médica dizem exatamente o contrário; por exemplo, recentemente uma menina deu à luz aos 11 anos; aos 14/05/1939 a peruana Lina Medina deu à luz aos 5 anos e 7 meses de idade”. Além de se basear em literatura médica duvidosa e contestável, o Padre Jonas Eduardo não faz menção à saúde mental das crianças submetidas a dar continuidade a tais gestações nem demonstra preocupação alguma nesse sentido.

Para a teóloga feminista Tabata Pastore Tesser (2019), os discursos do catolicismo silenciaram a voz das mulheres e aprisionaram seus corpos por séculos. Para ela, a Igreja é um lugar de domesticação dos corpos das mulheres através da fé. E ela entende duas doutrinas como essenciais neste processo de aprisionamento das mulheres: a primeira é a do casamento heterossexual indissolúvel entre um homem e uma mulher. Ou seja, o casamento terá de ser entre um homem cis e uma mulher cis, e esse par terá que ser mantido por toda a vida até a morte, a despeito do desejo dos envolvidos e das transformações que acontecem nos relacionamentos. Além disso, no casamento cristão existe uma aceitação romantizada de que o corpo das mulheres é propriedade dos maridos e a subserviência a eles é obrigatória, o que faz com que muitas mulheres suportem a violência doméstica em nome da fé. A segunda doutrina apontada pela autora é a da 'maternidade compulsória', pois, no casamento cristão, a função do corpo da mulher é a procriação, retirando os seus direitos reprodutivos.

Estas compreensões influenciaram profundamente nossa sociedade, como analisa Rodríguez (2008): muitos tratados de filósofos, moralistas, teólogos e políticos desenvolveram um pensamento excludente e repressivo da liberdade das mulheres, para sustentar a sujeição aos homens baseados em princípios biológicos ('lei natural’) e divinos ('Bíblia’). Defenderam que Deus e a natureza fizeram os seres femininos vulneráveis, incapazes de pensar, de governar-se ou conduzir-se por si próprias, por isso dependiam dos homens para as guiarem. As mulheres foram reduzidas a puro corpo sexual e reprodutivo, incapazes de assumirem espaços de conhecimento e poder político. Os homens acreditavam que, por meio do casamento, elas estavam obrigadas a lhes oferecerem serviços: sexual e reprodutivo, doméstico, pessoal e social, pelo fato de as sustentarem financeiramente. 
Quanto à diversidade sexual, a partir da lei natural, a Igreja Católica a considera uma desordem na criação divina. Conforme o Catecismo da Igreja Católica (1993, grifo nosso), no parágrafo 2357: “a tradição sempre declarou que os atos de homossexualidade são intrinsecamente desordenados. 'São contrários à lei natural'. Fecham o ato sexual ao dom da vida. Não procedem de uma complementaridade afetiva e sexual verdadeira. Em caso algum podem ser aprovados” .Nesse horizonte, a filósofa Judith Butler (2019), analisando a visão de sexualidade do catolicismo, especialmente seus ataques aos estudos de gênero, comenta que a igualdade de gênero é tomada como uma 'ideologia diabólica', pois os estudiosos desta área consideram a diversidade de gênero como uma construção histórico-social e rejeitam a ideia de que o gênero está determinado pelo sexo designado ao nascer, o que para a Igreja é considerado como a destruição de uma realidade e uma essência dada por Deus.

Baseados nestas doutrinas, os católicos conservadores e (neo)pentecostais têm promovido nos últimos anos uma verdadeira cruzada em tom de pânico moral. Seus discursos, como reflete Silva (2018), reforçam uma perspectiva conservadora da vida social. Ao orientar os fiéis para uma postura de intolerância diante da diversidade, em especial a de gênero e de orientação sexual. Os líderes religiosos essencializam um aspecto como natural, retirando os componentes históricos que engendram as relações sociais entre indivíduos. Parte significativa do sucesso desse discurso se efetiva na medida em que ele se ergue a partir do reforço da naturalização do status quo e da aceitação das diferenças como bases para a desigualdade.

2 “Se Deus é masculino, então, os homens são deuses”: ${ }^{4}$ da Teologia da Libertação à Teologia Feminista

A Teologia da Libertação (TL) nasceu na Igreja Católica no final da década de 1960 e início da década de 1970, como tentativa de resposta à contradição existente na América Latina entre a pobreza extrema e a fé cristã da maioria de sua população. (NORONHA, 2012) A principal expressão religiosa da TL são as Comunidades Eclesiais de Base (CEB), que possuem como princípio uma opção preferencial pelos mais pobres e são engajadas nas lutas de libertação, por exemplo, contra a ditadura militar, pela causa dos sem-terra, dos sem-teto, dos imigrantes. Assim, as CEBs e a TL possuem preocupações que não giram em torno de uma afirmação confessional-doutrinária para a sociedade, mas se pautam em projetos que transcendem a questão religiosa em si e defendem a separação entre a esfera política e a esfera religiosa, levantam bandeiras políticas como a demarcação de terras indígenas, a reforma agrária e a redistribuição de renda. Todavia, em seu período inicial, toda a dinâmica reflexiva da TL voltou-se para a

4 Pensamento elaborado pela teóloga Mary Daily amplamente difundido entre as teólogas feministas. 
perspectiva do pobre e de sua libertação. Em razão da atenção dedicada a esse tema, outros ângulos acabaram não entrando na pauta da reflexão, como o das culturas, das religiões e das relações de gênero. (TEIXEIRA, 2008) Porém, a partir das vivências nas relações com seus interlocutores na realidade latino-americana, como os povos indígenas, as religiões de matriz africana, os militantes ateus que participavam nas lutas populares e as mulheres do movimento feminista, a TL passou a desenvolver uma atitude de respeito e valorização das diferenças. (VIGIL, 2005)

Segundo a socióloga Neiva Furlin (2011), a TF emerge como uma outra voz no interior de um campo de saber majoritariamente masculino. É uma voz que resulta da consciência de um sujeito reflexivo, neste caso, de mulheres teólogas que passam a questionar os lugares que socialmente lhes foram outorgados como legítimos por um único discurso teológico produzido, em geral, por homens celibatários. Nesse sentido, a TF integra uma grande rede de saberes que emergiram em diferentes áreas acadêmicas, problematizando e desconstruindo os discursos hegemônicos androcêntricos. Saberes que emergem da consciência de uma experiência compartilhada de dominação, invisibilidade e discriminação vivida pelas mulheres no interior da Igreja.

Já no século XIX surge a primeira elaboração feminista de interpretação da bíblia, feita por mulheres especialistas na área. Elisabeth Cady Stanton publica, entre 1895 e 1898, nos Estados Unidos, um projeto coletivo de revisão e de reinterpretação da bíblia. Esse trabalho, publicado sob o título The Woman's Bible, é considerado o ponto de partida de um longo e fragmentado processo que levará, no final dos anos 60 do século XX, à constituição de uma TF. (ROSADO, 2001) Porém, segundo a historiadora Maristela Moreira de Carvalho (2006), a TF latino-americana narra a história de sua origem buscando certo afastamento do movimento feminista norte-americano e europeu, por identificá-lo a um movimento 'burguês e de Primeiro Mundo', ou seja, coisa de mulheres que estavam voltadas mais para as lutas individuais, sem preocupações com outras mulheres, em especial as dos setores populares.

Com esta motivação, a TF no Brasil, influenciada pela TL, desenvolveu-se com o objetivo de pensar o feminismo a partir da realidade concreta brasileira e latino-americana. A antropóloga feminista Rita Segato (2012), explica que o feminismo eurocêntrico, que afirma que o problema da dominação de gênero, da dominação patriarcal, é universal, sem maiores diferenças (classe, raça, etnia, orientação sexual), sustenta uma posição de superioridade moral das mulheres europeias ou eurocentradas. Por isso, a TF brasileira desde sua origem percebeu a necessidade de pensar a partir das mulheres latino-americanas. A freira e teóloga feminista Ivone Gebara, importante pioneira da TF no Brasil, por exemplo, começou a desenvolver sua teologia 
atuando em pastorais com as mulheres das periferias de Recife, onde conheceu a realidade dolorosa de muitas mulheres pobres e negras e passou a defender e lutar pela legalização do aborto. Nesse sentido, a TF oferece uma contribuição também para os feminismos pós-coloniais, pois desde a sua origem esteve comprometida em desenvolver uma epistemologia latinoamericana, incluindo a diversidade étnico e racial deste povo, contra a colonização do gênero pelo patriarcado europeu, branco e cristão. A TF, demonstrou que as mulheres cristãs latinoamericanas, assim como Femenías (2007) afirmou do feminismo latino-americano, têm algo a dizer em sua própria voz, com características e argumentos próprios desde a sua realidade, para romper com a condição de ‘outra’ do feminismo e da TF eurocêntrica.

Assim, o desenvolvimento da TF no Brasil remete suas origens à década de 1980, sinalizando a sua relação com a TL e com as CEBs, pois, segundo Leonardo Boff (1996, p. 66):

Houve um processo ligado aos cristãos de base e à TL que está elaborando e difundindo a Teologia Feminista da Libertação. Começou-se a descobrir a mulher como sujeito histórico oprimido e discriminado, dominado pelo machismo, pela cultura patriarcal e também pelo colonialismo capitalista ocidental.

Nesse sentido, as décadas de 1960 a 1980 foram marcadas não apenas pela grande mobilização das mulheres na luta pelos direitos civis, nos movimentos populares urbanos e rurais, mas também, no âmbito religioso, tanto na Igreja Católica quanto em certas Igrejas Evangélicas, pela formação e pela difusão das CEB's, nas quais setores importantes da população feminina católica foram incorporados ao projeto de constituição de uma 'Igreja dos Pobres’, sendo este o contexto do início da produção teológica feminista no continente. Ainda que o acesso das mulheres à teologia tenha ocorrido apenas na década de 1980, momento posterior à incorporação das mulheres nas CEBs e ao surgimento da TL, é este mesmo processo que mobiliza católicas - leigas das classes populares e religiosas - na constituição das CEB’s e acaba por integrar também algumas mulheres no processo de elaboração teológica. (CARVALHO, 2006)

No entanto, Ana Ester Pádua Freire (2015) analisa que, em seu desenvolvimento histórico, conforme a TF foi se aproximando das abordagens feministas, ela foi gradativamente afastando-se da TL, pois, o conceito de opressão sociopolítica que adotou não era suficiente para pensar a igualdade de gênero da TF. Gebara (2006) explica que o clamor da TL por justiça social não incluía justiça e igualdade de gênero, pois esta permaneceu encerrada em um ideário abstrato, não enfrentando a realidade colocada pela concretude da corporeidade e do sexo. Gebara não nega que a TF se inspirou na TL em muitos aspectos, apenas destaca que devido aos diferentes temas que trabalha e as alianças com o movimento feminista, ela tem se afastado da ortodoxia da TL, que ainda mantém uma imagem patriarcal de Deus, desenvolvendo uma nova 
epistemologia. Nas palavras de Regina Soares Jurkewicz (2017) atual coordenadora do grupo Católicas pelo Direito de Decidir, referindo-se à TL: “Nós falávamos dos pobres, mas não olhávamos para as mulheres”.

Figura 1 - Imagem das CDD para o Dia de Luta pela Descriminalização do Aborto na América Latina

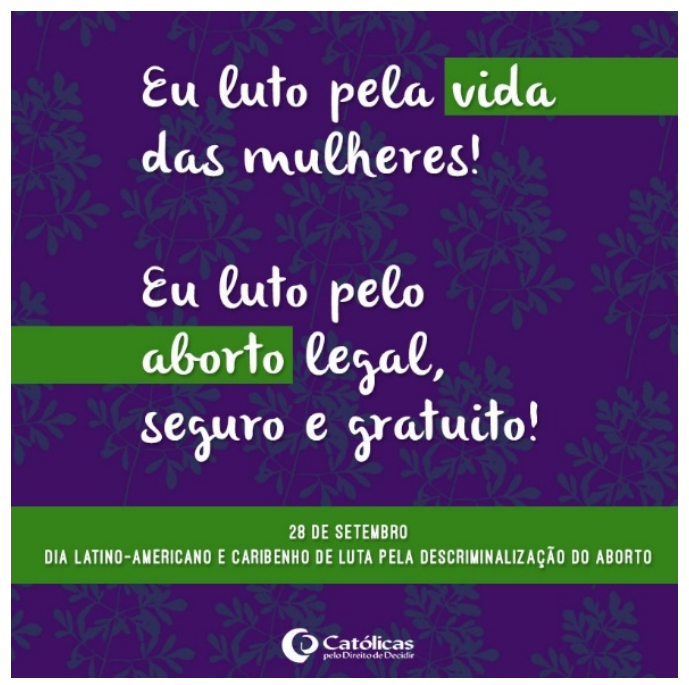

Fonte: Católicas pelo direito de decidir ${ }^{5}$.

A principal organização que tem atuado na luta pelos direitos das mulheres a partir de um discurso teológico católico é a ONG Católicas Pelo Direito de Decidir (CDD). Esta organização tem exercido um papel central no trabalho realizado para questionar o discurso do conservadorismo católico no campo dos direitos sexuais e reprodutivos na América Latina e, em particular, nos casos do México, Colômbia e Brasil. Conforme Alba Rubial (2014), essa organização apresenta um discurso dissidente da hierarquia católica, que interpela o catolicismo a partir de seu interior e desestabiliza a ideia de que a única interpretação congruente com a tradição católica é a defesa do modelo tradicional de família e a consequente proibição do aborto e a resistência ao avanço dos direitos sexuais e reprodutivos. De modo semelhante, a perspectiva trazida por essa organização tem tido um papel fundamental na construção do direito ao aborto em relação à liberdade de consciência e na demanda pela laicidade das políticas públicas.

As CDD surgiram durante a segunda onda feminista, como classifica Alvarez (2014), que possuía como marca a presença de muitas ONGs, assim, no espírito da época, suas integrantes constituíram-se e atuaram como uma ONG. A autora destaca que esta participação das mulheres de pastorais das igrejas, bem como de outros setores sociais, estimulou a proliferação de feminismos no plural. (ALVAREZ, 2014) Atualmente, segundo Marlise Matos (2010), o feminismo tem vivido uma nova onda, que assumiu como sentido orientador uma renovada ênfase em fronteiras interseccionais, transversais e transdisciplinares entre gênero, raça, 
sexualidade, classe e geração. Acompanhando esta tendência das teorias feministas, as teologias de gênero têm desenvolvido novas reflexões, como as teologias gays ${ }^{6}$, lésbicas $^{7}$ e queer ${ }^{8}$. Também estão surgindo novas experiências de coletivos de feministas religiosas, como as Evangélicas pela Igualdade de Gênero e a Frente Evangélica Pela Legalização do Aborto.

3 “Até Maria foi consultada para ser mãe de Deus": a laicidade do Estado e a democracia de gênero

As mulheres representam 52\% da população brasileira, porém, possuem uma baixa representatividade na política, que se reflete na ocupação de cargos de poder. Segundo o Mapa da Mulher na Política (2019), um relatório da Organização das Nações Unidas (ONU) divulgado no mês de março de 2019, no ranking de representatividade feminina no Parlamento, o Brasil ocupa a posição 134 de 193 países pesquisados, com 15\% de participação de mulheres. São 77 deputadas em um total de 513 cadeiras na Câmara, e somente 12 senadoras entre os 81 eleitos. Das 25 comissões permanentes da Casa, apenas 4, ou seja 16\%, são presididas por mulheres. Já no ranking de representatividade feminina no governo, o Brasil ocupa a posição 149 em um total de 188 países. O governo de Jair Bolsonaro tem somente 9\% de representatividade feminina, com apenas duas mulheres entre os 22 ministros. A média mundial é de 20,7\%.

Frente a estes dados, trazemos à tona o questionamento da feminista brasileira Teresa Kleba Lisboa (2017) refletindo sobre a democracia de gênero: podemos falar em democracia diante das desigualdades de gênero que se expressam diariamente, nos diferentes espaços da sociedade, nos quais milhares de mulheres estão sujeitas a injustiças, práticas de exclusão, confinamento ao espaço doméstico, discriminação, violência de todos os tipos, silenciamento, invisibilidade e hierarquias nos espaços de poder? Ainda segundo Lisboa (2017), todas as culturas, sociedade e pessoas elaboram cosmovisões sobre os gêneros. Assim, ela explica que as mulheres foram excluídas da política, pois a dimensão de gênero que permeou a construção da

6 A Teologia Gay surge logo após da revolução de Stonewall (1969), como um novo discurso procurando articular, teologicamente, as reivindicações do Movimento de Libertação Homossexual, desenvolvendo uma 'Teologia Gay da Libertação’. Um forte momento que marcou a reflexão teológica gay foi o surgimento da epidemia de HIV/Aids. Neste período, os teólogos gays buscaram desconstruir os discursos religiosos fundamentalistas que a consideravam como um castigo divino para purificar a sociedade e focaram a luta contra a morte como possibilidade de uma vida mais plena. (MUSSKOFP, 2019)

7 A Teologia Feminista Lésbica surgiu no início da década de 1980 sob a bandeira de que as mulheres lésbicas têm suas próprias vozes e suas próprias contribuições a fazer. Elas argumentam que a exclusão das lésbicas da religião não se dá propriamente por causa da questão da sexualidade, mas sim do poder. Como no casamento cristão a mulher é propriedade do homem, as relações sexuais entre duas mulheres apresentam a possibilidade única de igualdade entre as parceiras, libertando-se do domínio dos homens. (HUNT, 2019)

8 Surgindo na década de 1990, a Teologia Queer está na tensão entre abrir mão de uma teologia fundada em identidades e experiências estáticas. Partindo deste referencial, apropria-se de uma metodologia que expõe as contradições de uma sociedade e de uma religião fundadas no heterocentrismo, desestabilizando este sistema pelo reconhecimento de práticas que rompem as fronteiras do território heterocentricamente demarcado nos corpos. (MUSSKOFP, 2019)

Periódicus, Salvador, n. 16, v.1, set.2021-dez.2021 - Revista de estudos indisciplinares em gêneros e sexualidades Publicação periódica vinculada ao Núcleo de Pesquisa NuCuS, da Universidade Federal da Bahia - UFBA ISSN: 2358-0844 - Endereço: http://www.portalseer.ufba.br/index.php/revistaperiodicus 
sociedade democrática ocidental decretou que a mulher é inferior e privilegiou os homens, reservando-lhes o espaço social onde atuam, ou seja, o âmbito público. E destaca-se neste artigo que a construção de gênero no Brasil está fortemente relacionada com o cristianismo, especialmente em sua versão católica.

Como afirma a teóloga feminista Romi Bencke (2019), os elementos de uma religião patriarcal como o cristianismo nos espaços institucionais do exercício da política estão fortemente relacionados com a fragilização da democracia e a exclusão das mulheres da esfera pública. Desde o processo de colonização da América Latina, a Igreja Católica estava atuando na colonialidade do gênero, como analisa Lugones (2014). A confissão cristã, o pecado e a divisão maniqueísta entre o bem e o mal serviam para marcar a sexualidade feminina como maligna, uma vez que as mulheres colonizadas eram figuradas em relação a Satanás, às vezes como possuídas pelo Demônio. Assim, à medida que o cristianismo se tornou o instrumento mais poderoso da missão de transformação, a normatividade que conectava gênero e civilização concentrou-se no apagamento das práticas comunitárias ecológicas, saberes de cultivo, do cosmos, e não somente na mudança e no controle de práticas reprodutivas e sexuais.

Um exemplo da influência da moral católica sobre a sociedade brasileira é que o comportamento da mulher na primeira Constituição Brasileira foi normatizado pela Encíclica Papal Arcanum Divinae Sapientiae, de 1880. Esta Encíclica reafirmava os códigos domésticos de Efésios 5, 21-24, declarando que o chefe da família era o homem e que cabia à mulher submeterse ao marido, na qualidade de companheira, a fim de que fosse garantida a sua honestidade, a sua dignidade e a obediência que a esposa devia ao seu marido. No Código Penal de 1890 foi reafirmada, de maneira categórica, a importância da honra da mulher como condição básica para garantir a integridade das instituições do casamento e da família. Na Constituição de 1934, a Carta Magna contemplou o princípio da 'colaboração recíproca' entre Estado e Religião, abrindo espaço para a atuação das Igrejas em áreas como a educação, saúde, lazer e cultura. (BENCKE, 2019)

Porém, mesmo que a atual Constituição Brasileira de 1988 defina o Brasil como um Estado Laico, ${ }^{9}$ com a separação entre religião e Estado, o sociólogo da religião Gedeon Alencar (2016) ironiza sobre a Igreja Católica que ‘quem foi rei nunca perde a majestade’. O ideário

9 Conforme explica Gasda (2015), a laicidade é um conceito político que identifica um Estado moderno cuja legitimidade repousa na soberania do povo, ou seja, o Estado se afirma como independente de qualquer outra soberania que não seja o povo. O conceito de laicidade caracteriza a relação de autonomia entre o poder do Estado e o poder da religião. Ela possibilita uma dupla libertação: por um lado, o poder político se livra da tentação teocrática. Por outro, as religiões e os fiéis ficam imunes de governos que manipulam as religiões e a fé dos cidadãos. Assim, a laicidade é, sobretudo, um fenômeno político que expressa a neutralidade do Estado diante de grupos religiosos. Isto diferencia um Estado Laico de um 'Estado Confessional', que pauta sua organização e legislação obedecendo a prescrições determinadas pelas religiões. 
católico chegou com os colonizadores e nunca saiu do poder. Como símbolo de seu poder, há na Esplanada dos Ministérios uma capela que nem é ecumênica, é somente católica. Apenas com a emergência dos (neo)pentecostais na esfera pública o catolicismo encontrou concorrentes no poder político. Mas não foram os (neo)pentecostais que criaram este modo de relação entre religião e política, eles apenas se beneficiaram do modelo estabelecido pelo catolicismo. E mesmo que os (neo)pentecostais critiquem o catolicismo para terem os mesmos direitos que a Igreja Católica, os dois grupos possuem uma profunda unidade em torno das questões morais, especialmente de gênero e sexualidade. Por isso, o teólogo Juan Marco Vaggione (2019, p. 79) afirma que:

A Igreja Católica, sua hierarquia e discursos continuam sendo o principal obstáculo para a vigência dos direitos sexuais e reprodutivos nos países da América Latina. A Igreja transformou suas formas de exercer o poder, mas não renunciou à intenção de controlar o corpo, particularmente o das mulheres, como uma forma de controlar a ordem social em geral.

Figura 2 - Uma das fundadoras do grupo, Maria José Rosado-Nunes

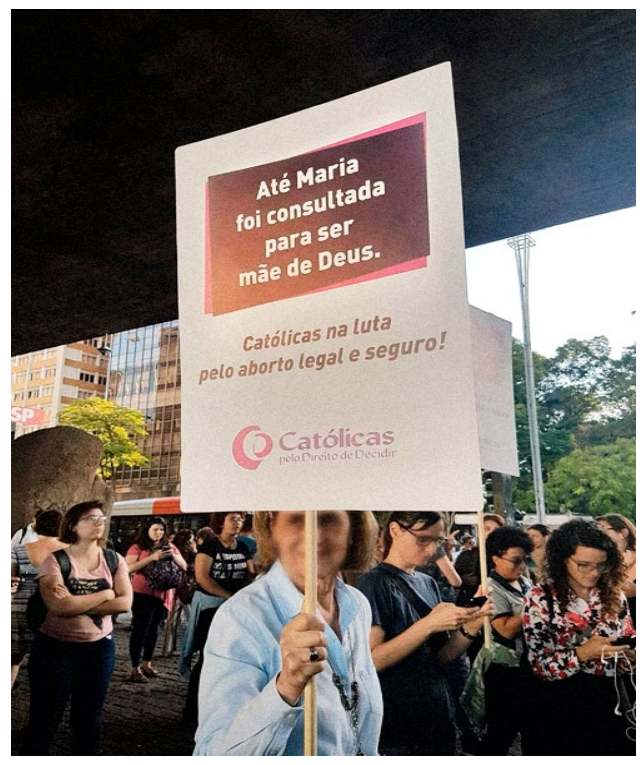

Fonte: $\mathrm{BBC}^{10}$.

As teólogas feministas têm problematizado esta relação entre a religião e o Estado, defendendo a total separação destas esferas de poder, por compreenderem que a laicidade é necessária para a libertação das mulheres e LGBTQIA+. Fundamentadas nesta concepção teológica, as CDD têm atuado junto aos movimentos feministas em todas as suas pautas, especialmente as relacionadas aos direitos sexuais e reprodutivos das mulheres. Mesmo que as articuladoras tenham saído das CEB’s, as CDD não estão sob a custódia da hierarquia católica, 
atuando como uma ONG, com trabalhos em parceria com o Ministério da Saúde e, especialmente, a Coordenadoria dos Direitos das Mulheres, organismos internacionais, assim como outras instituições, setores da sociedade civil e veículos da mídia brasileira. (BRITES, 2014) Elas atuam em organismos ecumênicos e civis por meio de formações, encontros, produção de pesquisas e materiais. Mas, diferente dos (neo)pentecostais e católicos conservadores que atuam por meio da política partidária, as CDD atuam nos movimentos sociais, fazendo presença em todas as grandes manifestações de mulheres. Mais recentemente, na audiência pública sobre a legalização do aborto de 2018, as CDD estiveram representadas por Maria José Rosado Nunes (2018), que proclamou: “imoral é que outros decidam sobre o que nós mulheres podemos ou não fazer dos nossos corpos, da nossa capacidade reprodutiva, da nossa vida. O Estado, a Igreja ou qualquer outra instância não pode decidir sobre isso”.

Como exemplo da reflexão teológica das CDD a favor dos direitos das mulheres, retomamos a luta democrática delas pela legalização do aborto. Como explicam Rodríguez e Vargas (2020), o movimento feminista tem realizado uma série de pesquisas que demonstram as consequências de uma gravidez não desejada para a saúde das mulheres como um problema de justiça social, bem como invocam a livre escolha dos indivíduos, de modo que as mulheres deveriam ter o direito de recorrer ou não, segundo as suas crenças, à interrupção da gravidez. Porém, o poder político, que é patriarcal, branco e cristão, impõe apenas uma crença a todas as mulheres. Como a maioria dos argumentos contra o aborto são religiosos, disfarçados de biológicos, a TF possui uma reflexão privilegiada neste debate, pois parte da linguagem religiosa, ela debate a partir de dentro da religião, com argumentos bíblicos e teológicos, sendo uma importante arma para o movimento feminista.

Para as CDD (2014, p. 7), na perspectiva da TF, não há na bíblia “uma só palavra a respeito de praticar ou não a limitação da natalidade [...] também não encontramos leis sobre o aborto, nem a favor, nem contra a sua legalização". Portanto, para elas a bíblia não pode ser tomada como um livro de perguntas e respostas para cada situação da vida, por isso elas recorrem à liberdade de consciência e afirmam que: "é preciso usar a inteligência e todas as capacidades humanas para entender o que Deus quer em cada época e em cada situação que enfrentamos”. (CDD, 2014, p. 8) Também na tradição da teologia católica sempre houve divergências quanto ao início da vida humana, quando o feto 'recebe' a alma. Por exemplo, Tertuliano condenava o aborto em todas as situações, já Santo Agostinho considerava que o aborto não poderia ser considerado um homicídio, pois não se poderia dizer que existia uma alma em um corpo que ainda carece de sensação. Santo Tomás de Aquino, no séc. XIII, afirmava que a união entre a alma e o corpo acontece 40 dias depois da concepção para homens e 80 para 
mulheres, por isso, o aborto antes desse período também não era homicídio. Assim, é muito recente a condenação do aborto em todos os casos, que se deu apenas com Pio IX, ao decretar que quem praticar o aborto em qualquer circunstância deverá ser excomungado da Igreja. (CDD, 2014) Assim, as Católicas enfatizam o caráter histórico da Igreja Católica, que mudou de posição em diversos casos, como o da escravidão, podendo também rever sua posição sobre o aborto, já que não se trata de um dogma de fé, nem possui fundamentação bíblica, sendo apenas norma disciplinar de uma igreja patriarcal.

Tendo em vista a importante contribuição que a TF pode trazer para o movimento feminista, à luz da reflexão de Teresa Kleba Lisboa (2017) sobre um 'pacto entre as mulheres' para a democracia de gênero, podemos pensar este pacto também em uma perspectiva de maior diálogo entre as feministas religiosas e não religiosas. Para Lisboa, a democracia de gênero é uma meta, uma utopia a ser alcançada, transformando as relações sociais de acordo com os princípios democráticos propostos em lei. O patriarcado também é entendido pela autora como um 'pacto entre varões’ para a manutenção de seus privilégios e exclusão das mulheres, inclusive da vida pública. Assim, como todas as pessoas vivem em relações marcadas pelo gênero, são necessários pactos intragenéricos, apenas entre mulheres, para lutarem por seus direitos. Mas também pactos intergenéricos, entre mulheres e homens comprometidos com a desconstrução do gênero, na busca por solidariedade e igualdade entre ambos.

Especificamente este pacto entre mulheres por vezes encontra alguns obstáculos que dificultam o diálogo, como questões de classe, raça, etnia, religião. Algumas barreiras ainda precisam ser derrubadas para a unificar a luta das mulheres. Nesse sentido, em 2019, algumas feministas religiosas e não religiosas iniciaram um processo de diálogo em busca de consenso contra o fundamentalismo religioso, que resultou na publicação de um relatório intitulado Laicidade e direito ao aborto: intersecções e conexões entre o debate feminista secular e feminista religioso. As mulheres feministas religiosas são aquelas que optam pela experiência de fé cristã, mas compreendem que a universalidade de uma análise teológica está enraizada tanto na profundidade, como na integridade e na legitimidade das diferentes experiências de Deus. Por isso não se furtam de dialogar e repensar seus conceitos para assumir novos discernimentos e mudanças de percepções. Já as mulheres feministas não religiosas, ou cresceram em ambientes familiares religiosos, principalmente cristãos, mas à medida que foram compreendendo a lógica patriarcal presente nesta tradição romperam com ela, ou nunca foram religiosas, porque cresceram em famílias ateias e/ou sem religião, sem esta vivência. Neste relatório, elas concluíram a importância de se estabelecerem mais diálogos entre o movimento feminista e a TF, pois no contexto brasileiro atual a religião, especialmente a cristã, tem sido cada vez mais 
um instrumento de condenação e negação dos direitos das mulheres. A partir disso, as feministas necessitam passar a observar mais este fenômeno, compreendendo que a religião está repercutindo em tudo e aprisionando as mulheres ao (e no) ambiente doméstico. (BENCKE, 2019)

Um último ponto apresentado por Teresa Kleba Lisboa (2017), que possui extrema importância na luta contra o fundamentalismo religioso, é que o 'pacto intergênero' e 'pacto intragênero’ deve vir acompanhado do ‘pacto intrapsíquico’, ou seja, no âmbito da subjetividade de cada pessoa consigo mesma, desconstruindo estereótipos de gênero na construção permanente e livre da sua formação como sujeito individual; é o momento de desconstruir o modo de pensar introjetado pela sociedade e pela religião. Este ponto toca diretamente a TF, pois, como reflete Ivone Gebara (2017), para além dos macropoderes da religião, existem os seus micropoderes, que são pouco lembrados nas análises de conjuntura do fenômeno religioso, como: o 'poder de sentido’, que faz a pessoa experimentar psicologicamente a convicção da existência de um sentido maior para a sua vida, podendo fazer o fiel aceitar sacrifícios como provas que Deus o submete porque vai lhe dar uma vida melhor depois desta; o 'poder do limite', que estabelece uma fronteira entre o que se deve ou não fazer, sendo uma forma poderosa de fazer as pessoas limitarem seus desejos e sua liberdade; o 'poder da segurança', que oferece o sentimento da pessoa estar mais segura em meio aos conflitos do cotidiano, pois conta com uma força oferecida por seres ou forças sobrenaturais. Estes micropoderes demonstram o papel complexo da religião para as lutas feministas e para a TF em sua reinterpretação e tentativa de inclusão das mulheres nos poderes simbólicos e institucionais da religião cristã, sendo que o corpo da maioria das mulheres se habituou a viver segundo a ordem religiosa patriarcal. E porque tocar nas crenças abala estruturas psíquicas, tradições culturais e familiares que sustentam a vida de muitas mulheres.

\section{Considerações finais}

Esta compreensão da Igreja Católica e dos (neo)pentecostais acerca do que é ser mulher, sobre a qual eles baseiam a sua atuação política, exemplifica o que Rita Segato (2017) tem analisado sobre a atual posição política em relação às mulheres. Para ela, estamos vendo no mundo a política trazer para o centro do palco um tipo de moral religiosa através do fundamentalismo cristão, que é o mesmo modelo de controle das mulheres no fundamentalismo islâmico, apenas com uma linguagem bíblica. Um modelo de controle social no qual você precisa das mulheres em uma posição subordinada, o que é muito perigoso, porque o fundamentalismo traz formas de fanatismo e guerra. Em entrevista ao Instituto Humanitas 
Unisinos, Segato (2017) apresentou como exemplo que, de Donald Trump a Mauricio Macri, a paisagem do espaço doméstico presidencial não obedece uma pauta de igualdade de gênero, mas, ao contrário, a da mulher em seu lugar - bela, recatada e do lar. Caso você pegue uma foto presidencial de Trump, de Michel Temer, de Bolsonaro, de Macri com as primeiras-damas, repete-se a cena. É um exemplo muito forte da subordinação da figura feminina.

Como apresentado ao longo deste artigo, a TF é um espaço privilegiado para a reflexão sobre gênero e religião. Porém, as teólogas feministas ainda ocupam um não-lugar, pois, por vezes, são vistas com preconceito pelo movimento feminista por serem religiosas e são silenciadas em suas Igrejas por defenderem pautas feministas que divergem da doutrina cristã oficial. Porém, as reflexões da TF desafiam a todo o movimento feminista, por mais que muitas militantes feministas não possuam nenhuma crença ou religião, ou sejam de outras religiões que não a cristã. Conhecer as reflexões da TF possibilita dialogar com a grande maioria das mulheres brasileiras, que são de tradição cristã, não apenas com argumentos que simplesmente critiquem a religião, mas que sejam formulados a partir de dentro do pensamento religioso, com uma linguagem compreensível ao universo simbólico destas mulheres, bem como aprender da TF seus sólidos argumentos bíblicos e teológicos que desconstroem a teologia hegemônica fundamentalista que ataca constantemente a laicidade do Estado e os direitos das mulheres, LGBTQIA+ e outras minorias.

\section{Referências}

ALENCAR, G. F. Política e pentecostalismos: apesar das traições mútuas, um casamento (quase) perfeito. In: ABUMANSSUR, E. S.; BARBOSA, C. A.; VALÉRIO, S. P. (org.). Pentecostalismos no Brasil contemporâneo: novas perspectivas. São Paulo: Reflexão, 2016. p. 43-67.

ALVAREZ, S. E. Para além da Sociedade civil: reflexões sobre o campo feminista. Cadernos Pagu, Campinas, n. 43, p. 13-56, 2014.

BENCKE, R. M. Laicidade e direito ao aborto: intersecções e conexões entre o debate feminista secular e feminista religioso. Brasília, DF: Centro Feminista de Estudo e Assessoria, 2019.

BOFF, L. A Teologia da Libertação: balanços e perspectivas. São Paulo: Ática, 1996.

BRITES, F. M. Católicas pelo Direito de Decidir: vozes dissonantes e discursos católicos sobre o aborto (1990-2010). Dissertação (Mestrado em História) Universidade Federal de Santa Catarina, Florianópolis, 2014. 
BUTLER, J. No disparen contra la ideología de género. Página|12, Buenos Aires, 1 fev. 2019. Disponível em: https://bit.ly/3bhj0FE. Acesso: 20 jan. 2020.

BRASIL. Câmara dos Deputados. Baixa representatividade de brasileiras na política se reflete na Câmara. Brasília, DF: Câmara dos Deputados, 2019. Disponível em: https://bit.ly/2QZk4Y3. Acesso: 7 fev. 2020.

CARVALHO, M. M. Teologia(s) Feministas(s) e Movimentos(s) Feminista(s) na América Latina e no Brasil: "origens" e memória. In: SEMINÁRIO INTERNACIONAL FAZENDO GÊNERO, 7., 2006, Florianópolis. Anais [...]. Florianópolis: UFSC, 2006. Disponível em: https://bit.ly/3vSJ9T8. Acesso: 8 fev. 2020.

CASTRO, C. S. Mulheres e RCC na América do Sul: uma revisão bibliográfica e um estudo de sites do movimento de Renovação Carismática Católica. Primeiros Estudos, São Paulo, n. 4, p. 144-155, 2013.

CATÓLICAS PELO DIREITO DE DECIDIR. Aborto: conversando a gente se entende. São Paulo: CDD, 2014.

EDUARDO, J. Resposta a Frei Betto. Canção Nova, Cachoeira Paulista, 2009. Disponível em: https://bit.ly/3oaIXMn. Acesso: 30 jan. 2020.

"EU ESTOU vivo por uma obra de Deus”, reconhece Bolsonaro. Guia Me, [s. l.] 2018. Disponível em: https://bit.ly/3o0x6k0. Acesso: 1 fev. 2020.

FEMENÍAS, M. L. Esbozo de un feminismo latino-americano. Estudos Feministas, Florianópolis, v. 15, n. 1, p. 11-25, 2007.

FREIRE, A. E. P. Teologia feminista: contribuições para o estudo do fenômeno religioso em uma perspectiva de gênero. Jesus Histórico, Rio de Janeiro, n. 15, p. 45-62, 2015.

FURLIN, N. Teologia feminista: uma voz que emerge nas margens do discurso teológico hegemônico. Rever: Revista de Estudos da Religião, São Paulo, v. 11, n. 1, p. 139-164, 2011.

GASDA, E. E. A laicidade ameaçada: política, religião e teologia. In: ROSSI, Luiz Alexandre; JUNQUEIRA, Sérgio (org.). Religião, Direitos Humanos $e$ Laicidade. São Paulo: Fonte, 2015. p. 39-57.

GEBARA, I. Entrevista. In: ROSADO-NUNES, M. J. Teologia feminista e a crítica da razão religiosa patriarcal: entrevista com Ivone Gebara. Estudos Feministas, Florianópolis, v. 14, n. 1, p. 294-304, 2006.

GEBARA, I. Mulheres, religião e poder: ensaios feministas. São Paulo: Terceira Via, 2017.

HUNT, M. Feministas lésbicas pioneiras na religião: uma forte fundação da teologia LGBTI+. In: JURKEWICZ, R. S. (org.). Teologias fora do armário: teologia, gênero e diversidade sexual. Jundiaí: Max, 2019. p. 92-112.

IGREJA CATÓLICA. Catecismo da Igreja Católica. Petrópolis: Vozes; 1993. 
JURKEWICZ, R. S. Os argumentos das católicas brasileiras que há 25 anos defendem o aborto. BBC, São Paulo, 18 dez. 2017. Disponível em: https://bbc.in/3o6hJXj. Acesso: 2 fev. 2019.

LISBOA, T. K. Democracia de Gênero: é possível um pacto entre as mulheres? O Social em Questão, Rio de Janeiro, ano 20, n. 38, p. 23-38, 2017.

LUGONES, M. Rumo a um feminismo decolonial. Revista Estudos Feministas, Florianópolis, v. 22, n. 3, p. 935-952, 2014.

MARÇAL, A. O fundamento do matrimonio na lei natural. Canção Nova, Cachoeira Paulista, 5 out. 2009. Disponível em: https://bit.ly/3f1AFlS. Acesso: 30 jan. 2020.

MATOS, M. Movimento e teoria feminista: é possível reconstruir a teoria feminista a partir do sul global? Revista de Sociologia e Política, Curitiba, v. 18, n. 36, p. 67-92, 2010.

MUSSKOFP, A. Teologias Gay/Queer. In: JURKEWICZ, R. S. (org.). Teologias fora do armário: teologia, gênero e diversidade sexual. Jundiaí: Max, 2019. p. 114-146.

NORONHA, C. U. A. Teologia da libertação: origem e desenvolvimento. Fragmentos de cultura, Goiânia, v. 22, n. 2, p. 185-191, 2012.

NUNES, M. J. R. Discurso na audiência pública sobre a legalização do aborto. In: BRASIL. Supremo Tribunal Federal. Católicas pelo Direito de Decidir defendem não intromissão do Estado ou da Igreja na questão do aborto. Brasília, DF: STF, 2018. Disponível em: https://bit.ly/33z5Wr3. Acesso: 3 fev. 2020 .

PY, F. Cristologia cristofascista de Bolsonaro. Revista IHU On-line, São Leopoldo, 2019. Disponível em: https://bit.ly/3o66gXS. Acesso: 1 fev. 2020.

RANKE-HEINEMANN, U. Eunucos pelo Reino de Deus: a Igreja Católica e a sexualidade: de Jesus a Bento XVI. Rio de Janeiro: Rosa dos Tempos, 2019.

RODRÍGUEZ, E. C.; VARGAS, L. I. Indentidad política y ciudadanía: los puentes de uma democracia por realizar. In: CASTAÑEDA, G. G. (org.). Democracia y luchas de género: la construcción de um nuevo campo teórico y político. México: Unam, 2002. p. 109-138.

RODRÍGUEZ, M. E. S. Hijas de la igualdad, herderas de injusticias. Madrid: Narcea, 2008.

ROSADO, M. J. O impacto do feminismo sobre o estudo das religiões. Cadernos Pagu, Campinas, n. 16, p. 79-96, 2001.

RUBIAL, A. M. Feminismo frente a fundamentalismos religiosos: mobilização e contramobilização em torno dos direitos reprodutivos na América Latina. Revista Brasileira de Ciência Política, Brasília, DF, n. 14, p. 111-138, 2014.

SEGATO, R. A base política das relações de violência de gênero. 2017. Revista IHU On-line, São Leopoldo, 11 ago. 2017. Disponível em: https://bit.ly/3vUFZhF. Acesso: 6 fev. 2020. 
SEGATO, R. Gênero e colonialidade: em busca de chaves de leitura e de um vocabulário estratégico descolonial. E-cadernos CES, [S. l.], n. 18, p. 106-131, 2012.

SILVA, E. F. "Em nome da natureza": discursos e mobilizações católicas no Brasil contra a inserção de discussões em torno do gênero na escola. Religare, São Paulo, v. 15, n. 2, p. 505-525, 2018.

TEIXEIRA, F. A teologia do pluralismo religioso na América Latina. In: VIGIL, J. et al. (org.). Teologia pluralista libertadora intercontinental. São Paulo: Paulinas, 2008. p. 21-40.

TESSER, T. P. Legitimação da violência contra as mulheres no discurso religioso hegemônico. In: JURKEWICZ, R. S. (org.). Teologias fora do armário: teologia, gênero e diversidade sexual. Jundiaí: Max, 2019. p. 74-90.

VAGGIONE, J. M. A Política da Dissidência: o papel de Católicas pelo Direito de Decidir na América Latina. In: JURKEWICZ, R. S. (org.). Entre dogmas e direitos: religião e sexualidade. Jundiaí: Maxprint, 2017. p. 77-101.

VIGIL, J. M. Muitos pobres, muitas religiões: a opção pelos pobres: lugar privilegiado para o diálogo entre as religiões. In: TOMITA, L. E.; BARROS, M.; VIGIL, J. M. (org.). Pluralismo e libertação: por uma teologia latinoamericana pluralista a partir da fé cristã. São Paulo: Paulinas, 2005. p.17-31. 